DOI: https://doi.org/10.24127/ajpm.v8i1.1890

\title{
LAPISAN PEMAHAMAN KONSEP MATEMATIKA DALAM SOAL PISA PADA SISWA SMA
}

\author{
Risky Dwi Setyawati ${ }^{1}$, Novisita Ratu ${ }^{2}$ \\ ${ }^{1,2}$ Pendidikan Matematika, Universitas Kristen Satya Wacana \\ E-mail: $\quad 202015032 @$ student.uksw.edu ${ }^{1)}$ \\ novisita.ratu@staff.uksw.edu $u^{2)}$
}

Received 20 Februari 2019; Received in revised form 1 April 2019; Accepted 10 May 2019

\begin{abstract}
This is a description qualitative research to describe the mathematic conceptual understanding layer in solving PISA questions for students in Grade X Senior High School. The research subjects are three students of Grade X MIPA 7 Negeri 1 State Senior High School Salatiga year of study 2018/2019, as the purposive sampling. Test and interview are used as the research data collection metodhs. The research results are for question number 1, Subject 1 reaches the level of formalising, Subject 2 reaches the level of investisingand Subject 3 reaches the level of observing. For question number, Subject 1 reaches the level image having, Subject 2 and 3 reaches the level of structuring. Next to question number 3, Subject 1 reaches the level of observing, Subject 2 reaches the level of investising and Subject 3 reaches the level of formalising.
\end{abstract}

Keywords: Qonceptual understanding layers; PISA; Quantity content

\section{PENDAHULUAN}

Kualitas pembelajaran saat ini sering dijadikan barometer perkembangan suatu negara, yang dilihat dari kemampuan siswa dalam menyelesaikan masalah sains, membaca dan matematika serta penerapannya dalam kehidupan sehari-hari (Johar, 2012). Kualitas pembelajaran tersebut diukur melalui hasil survey PISA yaitu Programme for International Students Assesment yang diselenggarakan 3 tahun sekali sejak tahun 2000 secara rutin untuk mengetahui pengetahuan tentang matematika, sains, dan keuangan serta literasi membaca pada siswa usia 15 tahun. Pada usia tersebut siswa umunya duduk di kelas 9 ataupun 10. Fokus penilaian PISA adalah kepandaian dalam membaca, menulis dan menghitung yang lebih menekankan kompetensi dan keterampilan siswa yang didapatkan di sekolah dan dapat dipraktikkan dalam kehidupan seharihari (OECD, 2009). Komponen soal PISA menguji 3 aspek yaitu aspek konteks, aspek proses dan aspek konten. Aspek konten terdiri dari empat yaitu uncertainty and data, space and shape, quantity, dan change and relationship. (OECD, 2012).

PISA memiliki fokus pada tiap kontennya, dalam konten quantity merupakan aspek matematis yang sangat luas dalam kehidupan. Quantity melibatkan pengukuran pemahaman, jumlah, besaran unit, indikator, ukuran relatif, serta berkaitan dengan hubungan bilangan maupun pola bilangan yang berhubungan dengan kehidupan seharihari. Pada konten ini dibutuhkan kemampuan menalar, memahami langkah dalam matematika, melakukan penaksiran kemudian mempresentasikannya dalam angka, serta berhitung di luar kepala (mental calculation) (OECD, 2013). Oleh karena itu, dalam menyelesaikan konten quantity dari soal PISA, siswa harus menguasai materi dalam konten-konten tersebut serta menerapkan pengetahuan 
matematikanya untuk memecahkan masalah yang berhubungan dengan kehidupan nyata.

Dibandingkan negara-negara lain rata-rata yang diperoleh Indonesia dalam PISA berada pada urutan sepuluh terbawah, terutama dalam literasi matematika (Puspitasari \& Ratu, 2019). Hal ini juga didukung dengan berdasarkan hasil penelitian Hawa dan Putra bahwa masih kurangnya kemampuan siswa dalam pemecahan masalah sehingga perkembangan Indonesia di setiap periode PISA belum menunjukkan hasil yang signifikan. Oleh karena itu, menurut Permendiknas No.22 tahun 2006 tentang Standar Isi mata pelajaran matematika, tindakan pemerintah Indonesia dalam menyusun kurikulum untuk menghadapi studi berskala internasional ini dengan tujuan diberikannya matematika kepada siswa mulai dari pendidikan dasar adalah agar dalam pembelajaran siswa memiliki kompetensi memahami konsep, dapat menjelaskan hubungan tiap konsep serta mengaplikasikanya, secara singkat, padat dan jelas serta tepat dalam pemecahan masalahnya. Sehingga pada pemecahan masalah soal matematika termasuk soal PISA dibutuhkan kemampuan yang lebih. Oleh karena itu untuk memecahkan masalah matematika termasuk soal PISA diperlukan Higher Order Thinking/ HOT atau kemampuan berpikir tingkat tinggi.

Kemampuan berpikir tingkat
tinggi timbul saat seseorang
mendapatkan informasi/ data baru
kemudian menghubungkannya dengan
data yang sudah dimiliki sebelumnya
kemudian disusun ulang serta dikaitkan
dan informasi tersebut dikembangkan
sehingga terwujud penyelesaian dari
suatu keadaan (Rosnawati, 2012).

Untuk memahami suatu pengetahuan baru, seseorang juga dapat menggunakan pengetahuan yang telah dimiliki dan dikolaborasikan dengan pengetahuan barunya. Hal tersebut menunjukkan bahwa pemahaman konsep berperan penting untuk memudahkan siswa dalam mempelajari matematika khususnya dalam memecahkan masalah. Oleh karena itu, untuk mencapai kemampuan berpikir tingkat tinggi membutuhkan pemahaman konsep (Cahyati, 2017).

Pentingnya pemahaman konsep terhadap suatu materi termasuk matematika dalam soal PISA menjadi salah satu hal yang wajib dikuasai oleh siswa, hal ini sesuai dengan kurikulum 2013 pada bagian kompetensi dasar (Safitri, Mulyani, \& Ratu, 2018). Menurut Permendikbud No.59 Tentang Kurikulum 2013, memahami konsep matematika terkait dengan kemampuan menjelaskan hubungan tiap konsep serta mengaplikasikanya, secara singkat, padat dan jelas serta tepat dalam pemecahan masalahnya. Apabila siswa mengalami kesulitan dalam memahami konsep matematika, maka siswa akan terhambat dalam penguasaan materi selanjutnya (Puspitasari \& Prihatnani, 2018).

Pirie dan Kieren (1994) menganggap pemahaman merupakan suatu proses yang tidak berakhir dan utuh. Proses itu merupakan proses pertumbuhan seperti bawang yang memiliki lapisan dan tidak akan berakhir. Lapisan pemahaman tersebut terdapat delapan lapisan yaitu: primitive knowing $(\mathrm{Pk})$ atau pengetahuan dasar, image making (Im) atau pembuatan gambaran, image having/ knowing (Ik) atau pemilikan gambar, property noticing (Pn) atau perhatian pada sifatsifat, formalising (Fo) atau 
pemformalan, observing (Ob) atau pengamatan, structuring (St) atau penataan, dan inventising (In) atau penciptaan. Sesuai dengan pengertian pemahaman yang merupakan suatu proses yang tidak akan berakhir, sehingga pemahaman pada inventising sering menjadi primitive knowing materi baru. Lapisan Pirie-Kieren dapat dilihat pada Gambar 1.

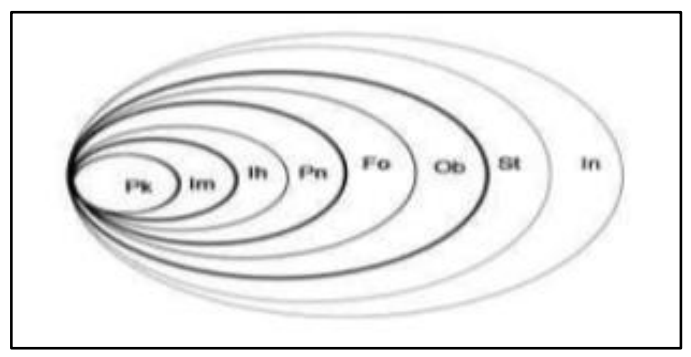

Gambar 1. Lapisan Pemahaman Konsep Menurut Pirie \& Kieren (Sagala, 2017)

Keterangan :

$\mathrm{Pk}$ : Primitive Knowing

Im : Image Making

Ik : Image Knowing / Having

Pn : Primitive Noticing

Fo : Formalising

Ob : Observing

St : Structuring

In : Inventising

Berdasarkan latar belakang, dan permasalahan penelitian diatas maka fokus dari penelitian ini yaitu lapisan pemahaman konsep matematika dalam soal PISA dimana penelitian ini belum banyak dilakukan oleh peneliti terdahulu dan dapat dirumuskan tujuan dari penelitian ini adalah untuk mendeskripsikan lapisan pemahaman konsep matematika dalam soal PISA pada siswa SMA kelas X. Penelitian ini diharapkan dapat mengetahui sampai sejauh mana lapisan pemahaman konsep yang dimiliki siswa SMA dalam menyelesaikan soal PISA, sehingga dapat menjadi bahan refleksi bagi guru untuk meningkatkan kualitas pembelajarannya.

\section{METODE PENELITIAN}

Penelitian ini adalah penelitian deskriptif kualitatif. Penelitian dilaksanakan pada bulan januari hingga Agustus 2018 dengan subjek penelitian ini adalah siswa kelas X MIPA 7 SMA Negeri 1 Salatiga tahun ajaran 2018/2019 yang terdiri dari 3 siswa dengan cara teknik purposive sampling atas dasar pertimbangan dan masukan dari guru dengan ketentuan sebagai berikut :
1. Mempunyai kemampuan menyelesaiakan soal yang dilihat berdasarkan hasil tes dan pengamatan

2. Dapat bekerjasama dengan peneliti

3. Mampu berkomunikasi dengan baik untuk menjelaskan hasil pemikirannya

Instrumen yang digunakan dalam penelitian adalah instrumen utama dan instrumen pendukung, dimana instrumen utama adalah peneliti itu sendiri, sedangkan instrumen pendukung adalah tiga soal PISA konten quantity. Teknik pengumpulan data dalam penelitian ini adalah observasi yaitu mengamati sebelum dan saat penelitian berlangsung, tes yaitu dengan memberikan soal PISA, dan wawancara yaitu untuk melengkapi data yang dianggap kurang.

Teknik analisis data dalam penelitian ini menggunakan tiga cara yaitu reduksi data yaitu dengan pemilihan dan merangkum data-data, penyajian data dengan menyajikan data setiap nomor berdasarkan hasil analisis terhadap indikator, dan penarikan kesimpulan yaitu dengan mengambil kesimpulan berdasarkan data yang telah 
DOI: https://doi.org/10.24127/ajpm.v8i1.1890

terkumpul. Berikut merupakan indikator yang digunakan dalam mengukur tiap lapisan pemahaman konsep soal PISA konten Quantity.

Tabel 1. Lapisan Pemahaman Konsep Soal PISA Konten Quantity

\begin{tabular}{|c|c|c|}
\hline No. & Lapisan & Indikator \\
\hline 1. & $\begin{array}{l}\text { Primitive } \\
\text { knowing }\end{array}$ & $\begin{array}{l}\text { Siswa dapat } \\
\text { mengetahui apa yang } \\
\text { ditanya dalam soal, } \\
\text { dapat menceritakan } \\
\text { kembali soal atau } \\
\text { menjelaskan } \\
\text { kembali }\end{array}$ \\
\hline 2. & $\begin{array}{l}\text { Image } \\
\text { Making }\end{array}$ & $\begin{array}{ll}\text { Siswa dapat } & \text { merencanakan } \\
\text { langkah apa yang } \\
\text { harus dilakukan }\end{array}$ \\
\hline 3. & $\begin{array}{l}\text { Image } \\
\text { having }\end{array}$ & $\begin{array}{l}\text { Siswa dapat } \\
\text { menyusun langkah- } \\
\text { langkah } \\
\text { penyelesaian }\end{array}$ \\
\hline 4. & $\begin{array}{l}\text { Property } \\
\text { noticing }\end{array}$ & $\begin{array}{l}\text { Siswa dapat } \\
\text { menghubungkan } \\
\text { rencana yang } \\
\text { digunakan dengan } \\
\text { konsep dan sifat-sifat } \\
\text { yang ada }\end{array}$ \\
\hline 5. & Formalising & $\begin{array}{l}\text { Siswa dapat } \\
\text { mengaplikasikan } \\
\text { rencana yang } \\
\text { digunakan dengan } \\
\text { konsep dan sifat- } \\
\text { sifat yang ada }\end{array}$ \\
\hline 6. & Observing & $\begin{array}{lr}\text { Siswa dapat } \\
\text { menggunakan } \\
\text { konsep dan sifat- } \\
\text { sifat } & \text { yang } \\
\text { dihubungkan pada } \\
\text { penyelesaian soal, } \\
\text { atau melakukan } \\
\text { pengecekan } \\
\text { kembali }\end{array}$ \\
\hline 7. & Structuring & Siswa dapat \\
\hline
\end{tabular}

\begin{tabular}{ll}
\hline & menyelesaikan soal \\
& tersebut secara \\
terstruktur \\
8. Inventising dapat \\
Siswa atau \\
menyimpulkan at baru \\
membuat \\
pertanyaan berkaitan \\
yang dengan soal \\
\hline
\end{tabular}

\section{HASIL PENELITIAN DAN PEMBAHASAN}

Berdasarkan hasil analisis jawaban tes dan hasil wawancara yang dilakukan terhadap tiga subjek dengan tiga soal mengenai soal PISA konten quantity. Berikut merupakan pembahasan hasil pekerjaan subjek.

Analisis Soal Nomor 1

1. Gunung Fuji hanya membuka pendakian untuk umum dari $1 \mathrm{Juli}$ hingga 27 Agustus setiap tahun. Selama periode waktu tersebut, terdapat 200.000 orang pendaki Gunung Fuji. Berapa rata-rata banyaknya pendaki Gunung Fuji tiap hari?
340
d. 7100
710
e. 7400

3400

Subjek 1

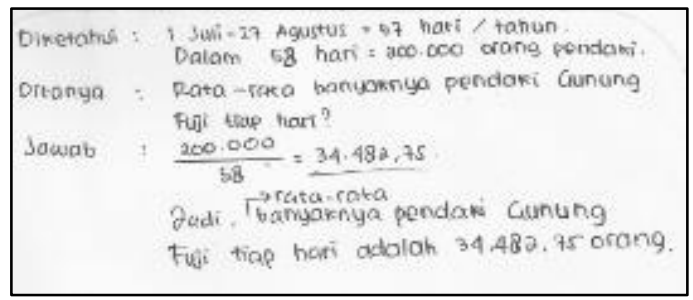

Gambar 2. Hasil Pekerjaan Subjek 1 pada Soal Nomor 1 
Berdasarkan hasil tes pada Gambar 2 dan wawancara Subjek 1 dapat menyelesaikan soal PISA konten quantity mengenai berapa rata-rata banyaknya pendaki Gunung Fuji tiap hari dengan jawaban $34.482,75$ orang, dimana telah mencapai lapisan pemahaman konsep yang kelima yaitu formalising. Subjek 1 dapat melakukan usaha awal dalam memahami yaitu primitive knowing, selanjutnya merencanakan langkah-langkah yang akan dilakukan untuk menyelesaikan soal yaitu image making, dan menuliskan apa yang terdapat pada lapisan sebelumnya dalam bentuk diketahui, ditanya dan jawab sehingga Subjek 1 dapat melewati lapisan image having. Subjek 1 juga dapat menghubungkan gambaran abstrak yang dimiliki dengan konsep dan sifat-sifat pada soal yaitu kuota pendaki dibagi dengan jumlah hari, hal ini berarti Subjek 1 melewati property noticing, selanjutnya Subjek 1 dapat mengaplikasikan sifat-sifat yang telah diketahui pada level sebelumnya dengan tepat dimana Subjek 1 dapat menyelesaikan pembagian antara kuota pendaki dengan jumlah hari karena kurang teliti dalam menghitung sehingga Subjek 1 dapat mencapai lapisan pemahaman konsep yaitu dan formalising.

\section{Subjek 2}

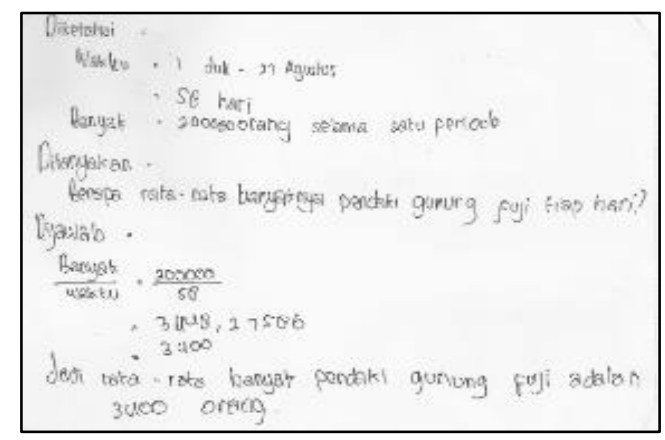

Gambar 3. Hasil Pekerjaan Subjek 2 pada Soal Nomor 1
Berdasarkan hasil tes pada Gambar 3 dan wawancara Subjek 2 dapat menyelesaikan soal PISA konten quantity mengenai berapa rata-rata banyaknya pendaki Gunung Fuji tiap hari dengan jawaban 3.400 orang, mencapai lapisan pemahaman konsep yang kedelepan yaitu investising. Subjek 2 dapat melakukan usaha awal dalam memahami yaitu primitive knowing, selanjutnya merencanakan langkah-langkah yang akan dilakukan untuk menyelesaikan soal yaitu image making, dan menuliskan apa yang terdapat pada lapisan sebelumnya dalam bentuk diketahui, ditanya dan jawab sehingga Subjek 2 dapat melewati lapisan image having. Subjek 2 juga dapat menghubungkan gambaran abstrak yang dimiliki dengan konsep dan sifat-sifat pada soal yaitu kuota pendaki dibagi dengan jumlah hari, hal ini berarti Subjek 2 melewati property noticing, selanjutnya Subjek 2 juga dapat mengaplikasikan sifat-sifat yang telah diketahui pada level sebelumnya dengan tepat dimana Subjek 2 dapat menyelesaikan pembagian antara kuota pendaki dengan jumlah hari hal itu menunjukkan Subjek 2 melewati formalising.

Subjek 2 dapat mengecek kembali penyelesaian dari awal, kemudian menyusun penyelesaian soal secara terstruktur dan lengkap sehingga dapat melewati lapisan observing dan structuring. Selanjutnya Subjek 2 juga dapat menyimpulkan apa yang telah diselesaikan sehingga dapat melewati lapisan kedelapan yaitu investising. 
Subjek 3

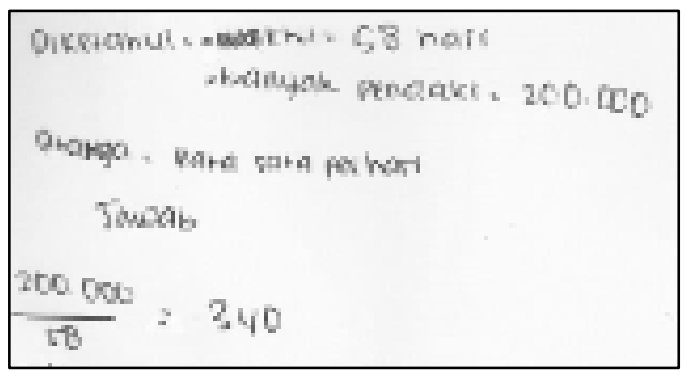

Gambar 4. Hasil Pekerjaan Subjek 3 pada Soal Nomor 1

Berdasarkan hasil tes pada Gambar 4 dan wawancara Subjek 3 dapat menyelesaikan soal PISA konten quantity mengenai berapa rata-rata banyaknya pendaki Gunung Fuji tiap hari dengan jawaban 340 orang, mencapai lapisan pemahaman konsep yang keenam yaitu observing. Subjek 2 dapat melakukan usaha awal dalam memahami yaitu primitive knowing, selanjutnya merencanakan langkahlangkah yang akan dilakukan untuk menyelesaikan soal yaitu image making, dan menuliskan apa yang terdapat pada lapisan sebelumnya dalam bentuk diketahui, ditanya dan jawab sehingga Subjek 2 dapat melewati lapisan image having. Subjek 2 juga dapat menghubungkan gambaran abstrak yang dimiliki dengan konsep dan sifat-sifat pada soal yaitu kuota pendaki dibagi dengan jumlah hari, hal ini berarti Subjek 2 melewati property noticing, selanjutnya Subjek 2 juga dapat mengaplikasikan sifat-sifat yang telah diketahui pada level sebelumnya dengan tepat dimana Subjek 2 dapat menyelesaikan pembagian antara kuota pendaki dengan jumlah hari hal itu menunjukkan Subjek 2 melewati formalising.

Subjek 3 mengecek kembali jawabannya, dan namun saat wawancara Subjek 3 mengetahui jika jawabannya tidak tepat, walaupun saat mengerjakan S3 tidak mengecek kembali. Sehingga dapat dikatakan S3 dapat melewati lapisan pemahaman observing.

Analisis soal nomor 2

2. Putra menggunakan alat ukur untuk menghitung banyaknya langkah di sepanjang jalur Gotemba. Alat ukurnya menunjukkan bahwa Putra berjalan sebanyak 22.500 langkah. Perkirakan rata-rata panjang langkah Putra ketika berjalan di sepanjang $9 \mathrm{~km}$ jalur Gotemba. Berikan jawabanmu dalam sentimeter $(\mathrm{cm})$.

Subjek 1

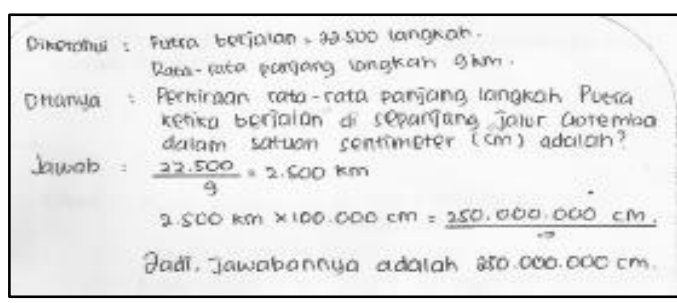

Gambar 5. Hasil pekerjaan Subjek 1 pada Soal Nomor 2

Berdasarkan hasil tes pada Gambar 5 dan wawancara Subjek 1 dapat menyelesaikan soal PISA konten quantity mengenai berapa rata-rata panjang langkah Putra ketika berjalan di Jalur Gotemba dengan jawaban $250.000 .000 \mathrm{~cm}$, mencapai lapisan pemahaman konsep yang image having . Subjek 1 dapat melakukan usaha awal dalam memahami yaitu primitive knowing, selanjutnya merencanakan langkah-langkah yang akan dilakukan untuk menyelesaikan soal yaitu image making, dan menuliskan apa yang terdapat pada lapisan sebelumnya dalam bentuk diketahui, ditanya dan jawab sehingga Subjek 1 dapat melewati lapisan image having. Subjek 1 tidak 
dapat menghubungkan gambaran abstrak yang dimiliki dengan konsep dan sifat-sifat pada soal dimana Subjek 1 menyelesaikan dengan membagi banyak langkah dengan panjang Jalur Gotemba kemudian dikalikan dengan 100.000, hal ini berarti Subjek tidak dapat melewati property noticing. Sehingga Subjek 1 hanya sampai lapisan yang ketiga yaitu image having.

\section{Subjek 2}

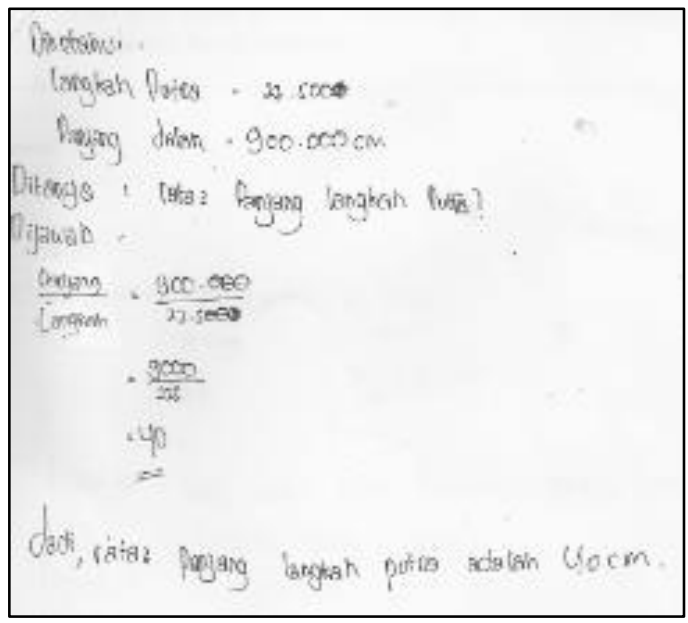

Gambar 6. Hasil pekerjaan Subjek 2 pada Soal Nomor 2

Berdasarkan hasil tes pada Gambar 6 dan wawancara Subjek 2 dapat menyelesaikan soal PISA konten quantity mengenai berapa rata-rata panjang langkah Putra ketika berjalan di Jalur Gotemba dengan jawaban $40 \mathrm{~cm}$, mencapai lapisan pemahaman konsep kedelapan yaitu investising. Subjek 2 dapat melakukan usaha awal dalam memahami yaitu primitive knowing, selanjutnya merencanakan langkahlangkah yang akan dilakukan untuk menyelesaikan soal yaitu image making, dan menuliskan apa yang terdapat pada lapisan sebelumnya dalam bentuk diketahui, ditanya dan jawab sehingga Subjek 2 dapat melewati lapisan image having. Subjek 2 juga dapat menghubungkan gambaran abstrak yang dimiliki dengan konsep yaitu mengubah $9 \mathrm{~km}$ ke dalam $\mathrm{cm}$ menjadi $900.000 \mathrm{~cm}$, kemudian Subjek 2 juga dapat mengaplikasikan sifat-sifat yang telah diketahui pada level sebelumnya dengan tepat, yaitu dengan membagi panjang jalan dengan banyaknya langkah Putra, sehingga S2 dapat mencapai lapisan pemahaman konsep yaitu property noticing dan formalising. Subjek 2 mengecek kembali langkah-langkah penyelesaian yang telah dikerjakan, serta menyusun penyelesaian soal secara terstruktur dan lengkap sehingga menghasilkan penyelesaian dari ratarata panjang langkah Putra yaitu $40 \mathrm{~cm}$. Hal ini terlihat bahwa Subjek 2 dapat menyelesaikan jawaban secara tepat, sehingga Subjek 2 dapat melewati lapisan observing dan structuring.

Selanjutnya Subjek 2 dapat menyimpulkan bahwa panjang langkah Putra yaitu sekitar $40 \mathrm{~cm}$. Sehingga Subjek 2 mencapai lapisan kedelapan yaitu investising.

Subjek 3

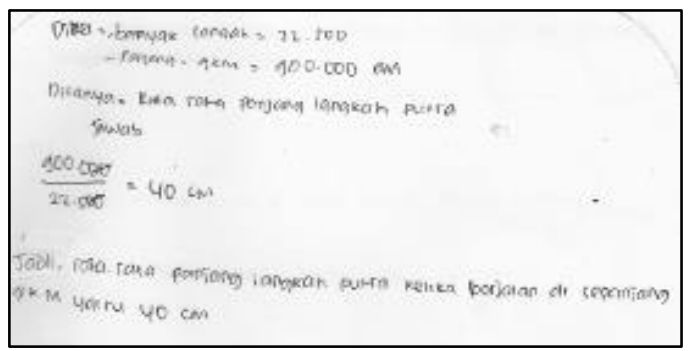

Gambar 7. Hasil pekerjaan Subjek 3 pada Soal Nomor 2

Berdasarkan hasil tes pada Gambar 7 dan wawancara Subjek 3 dapat menyelesaikan soal PISA konten quantity mengenai berapa rata-rata panjang langkah Putra ketika berjalan di Jalur Gotemba dengan jawaban $40 \mathrm{~cm}$, mencapai lapisan pemahaman konsep kedelapan yaitu investising. Subjek 3 dapat melakukan usaha awal dalam 
memahami yaitu primitive knowing, selanjutnya merencanakan langkahlangkah yang akan dilakukan untuk menyelesaikan soal yaitu image making, dan menuliskan apa yang terdapat pada lapisan sebelumnya dalam bentuk diketahui, ditanya dan jawab sehingga Subjek 3 dapat melewati lapisan image having. Subjek 3 juga dapat menghubungkan gambaran abstrak yang dimiliki dengan konsep yaitu mengubah $9 \mathrm{~km}$ ke dalam cm menjadi $900.000 \mathrm{~cm}$, kemudian Subjek 3 juga dapat mengaplikasikan sifat-sifat yang telah diketahui pada level sebelumnya dengan tepat, yaitu dengan membagi panjang jalan dengan banyaknya langkah Putra, sehingga Subjek 3 dapat mencapai lapisan pemahaman konsep yaitu property noticing dan formalising. Subjek 3 mengecek kembali langkahlangkah penyelesaian yang telah dikerjakan, serta menyusun penyelesaian soal secara terstruktur dan lengkap sehingga menghasilkan penyelesaian dari rata-rata panjang langkah Putra yaitu $40 \mathrm{~cm}$. Hal ini terlihat bahwa Subjek 3 dapat menyelesaikan jawaban secara tepat, sehingga Subjek 3 dapat melewati lapisan observing dan structuring.

Selanjutnya Subjek 3 dapat menyimpulkan bahwa panjang langkah Putra yaitu sekitar $40 \mathrm{~cm}$. Sehingga Subjek mencapai lapisan kedelapan yaitu investising.
Analisis Soal Nomor 3

3. Hani meneliti bagaimana ukuran koloni penguin akan berubah selama beberapa tahun ke depan. Untuk menentukannya, ia membuat asumsi sebagai berikut:

- Pada awal tahun, koloni itu terdiri dari 10.000 penguin (5.000 pasangan).

- Setiap pasangan penguin memiliki satu anak pada bulan April setiap tahun.

- Pada akhir tahun, 20\% dari jumlah penguin (dewasa dan anak) akan mati.

Pada akhir tahun pertama, berapa banyak penguin (dewasa dan anak) yang ada di koloni tersebut?

Subjek 1

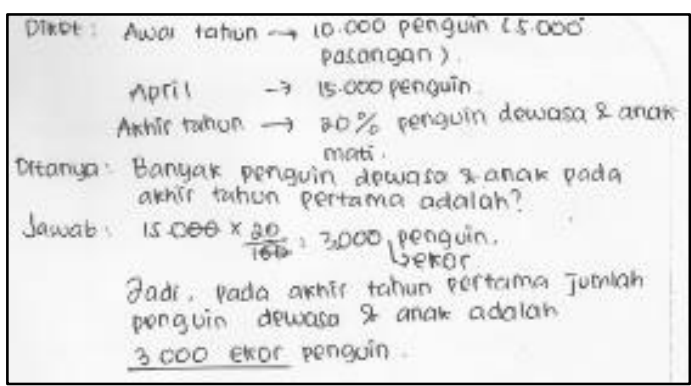

Gambar 8. Hasil pekerjaan Subjek 1 pada Soal Nomor 3

Berdasarkan hasil tes pada Gambar 8 dan wawancara Subjek 1 dapat menyelesaikan soal PISA konten quantity mengenai banyaknya penguin dalam koloni pada akhir tahun pertama dengan jawaban 3.000 ekor, mencapai lapisan pemahaman konsep kedelapan yaitu observing. Subjek 1 dapat melakukan usaha awal dalam memahami yaitu primitive knowing, selanjutnya merencanakan langkahlangkah yang akan dilakukan untuk 
menyelesaikan soal yaitu image making, dan menuliskan apa yang terdapat pada lapisan sebelumnya dalam bentuk diketahui, ditanya dan jawab sehingga Subjek 1 dapat melewati lapisan image having. Subjek 1 juga dapat menghubungkan gambaran abstrak yang dimiliki dengan menyebutkan berapa banyak penguin pada bulan April, kemudian total penguin tersebut dikalikan 20\%, kemudian Subjek 1 juga dapat mengaplikasikan sifat-sifat yang telah diketahui pada level sebelumnya dengan tepat, yaitu dengan mensubtitusikan angka-angka kemudian diperoleh jawaban 3.000 penguin, sehingga Subjek 1 dapat mencapai lapisan pemahaman konsep yaitu property noticing dan formalising. Subjek 1 telah mengecek kembali langkah-langkah penyelesaian dan hasilnya, walaupun Subjek 1 sudah yakin benar namun ternyata Subjek 1 masih belum tepat, dengan demikian Subjek 1 dapat melewati lapisan pemahaman observing, namun tidak dapat melewati lapisan pemahaman structuring dimana Subjek 1 tidak dapat menyusun penyelesaian soal secara terstruktur dan lengkap, serta tidak dapat membuktikan hasil pekerjaannya. Sehingga Subjek 1 hanya sampai pada lapisan pemahaman keenam yaitu lapisan pemahaman observing.

\section{Subjek 2}

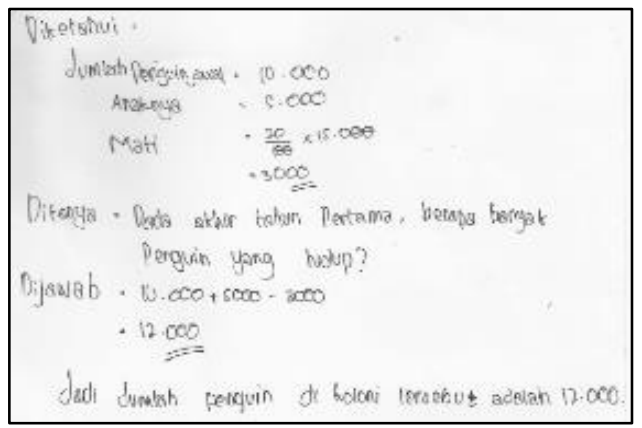

Gambar 9. Hasil Pekerjaan Subjek 2 pada Soal Nomor 3
Berdasarkan hasil tes pada Gambar 9 dan wawancara Subjek 2 dapat menyelesaikan soal PISA konten quantity mengenai banyaknya penguin dalam koloni pada akhir tahun pertama dengan jawaban 12.000 ekor, mencapai lapisan pemahaman konsep kedelapan yaitu investising. Subjek 2 dapat melakukan usaha awal dalam memahami yaitu primitive knowing, selanjutnya merencanakan langkahlangkah yang akan dilakukan untuk menyelesaikan soal yaitu image making, dan menuliskan apa yang terdapat pada lapisan sebelumnya dalam bentuk diketahui, ditanya dan jawab sehingga Subjek 2 dapat melewati lapisan image having. Subjek 2 juga dapat menghubungkan gambaran abstrak yang dimiliki dengan menjumlahkan banyaknya penguin awal dengan anak penguin, hasil tersebut dikalikan $20 \%$ sehingga diperoleh penguin yang mati, kemudian dari total penguin awal dengan anak penguin dikurangi dengan penguin yang mati, kemudian Subjek 2 juga dapat mengaplikasikan sifat-sifat yang telah diketahui pada level sebelumnya dengan tepat, yaitu jumlah penguin awal sebanyak 10.000 dan anak penguin sebanyak 5.000 sehingga hasilnya adalah 15.000, banyaknya penguin yang mati yaitu $20 \%$ dari 15.000 diperoleh 3.000, kemudian 15.000 dikurangi 3.000 diperoleh 12.000, sehingga Subjek 2 dapat mencapai lapisan pemahaman konsep yaitu property noticing dan formalising. Subjek 2 telah mengecek kembali langkah-langkah penyelesaian dan dapat menyusun penyelesaian soal secara terstruktur dan lengkap, serta dapat menyimpulkan apa yang diperoleh dari soal tersebut dengan demikian Subjek 2 dapat melewati lapisan pemahaman observing, structuring dan investising. 
Subjek 3

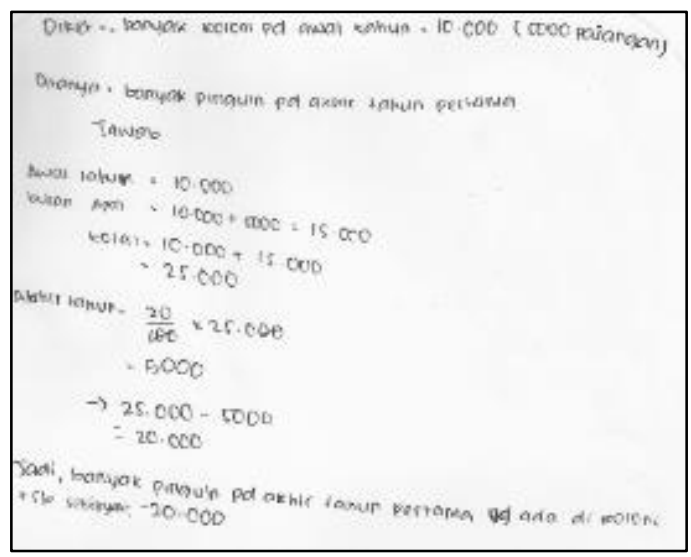

Gambar 10. Hasil Pekerjaan Subjek 3 pada Soal Nomor 3

Berdasarkan hasil tes pada Gambar 10 dan wawancara Subjek 3 dapat menyelesaikan soal PISA konten quantity mengenai banyaknya penguin dalam koloni pada akhir tahun pertama dengan jawaban 20.000 ekor, mencapai lapisan pemahaman konsep kedelapan yaitu formalising. Subjek 3 dapat melakukan usaha awal dalam memahami yaitu primitive knowing, selanjutnya merencanakan langkahlangkah yang akan dilakukan untuk menyelesaikan soal yaitu image making, dan menuliskan apa yang terdapat pada lapisan sebelumnya dalam bentuk diketahui, ditanya dan jawab sehingga Subjek 3 dapat melewati lapisan image having. Subjek 3 juga dapat menghubungkan gambaran abstrak yang dimiliki dengan menjumlahkan banyaknya penguin awal dengan banyaknya penguin pada bulan April, hasil tersebut dikalikan 20\% sehingga diperoleh penguin yang mati, kemudian dari total penguin awal dengan penguin pada bulan April dikurangi dengan penguin yang mati, kemudian Subjek 2 juga dapat mengaplikasikan sifat-sifat yang telah diketahui pada level sebelumnya yaitu mensubtitusikan jumlah penguin awal sebanyak 10.000 dan penguin pada bulan April sebanyak 15.000 sehingga hasilnya adalah 25.000 , banyaknya penguin yang mati yaitu $20 \%$ dari 25.000 diperoleh 5.000, kemudian 25.000 dikurangi 5.000 diperoleh 15.000 sehingga Subjek 3 dapat melewati lapisan pemahaman konsep yaitu formalising. Subjek 3 tidak mengecek kembali langkah-langkah penyelesaian soal sehingga Subjek 3 tidak dapat melewati lapisan berikut. Oleh karena itu Subjek 3 hanya dapat mencapai lapisan pemahaman kelima yaitu formalising.

Hasil analisis dan wawancara yang dilakukan di SMA Negeri 1 Salatiga menunjukkan hasil lapisan pemahaman konsep matematika dalam menyelesaikan soal PISA konten quantity setiap siswa berbeda-beda, seperti pada Gambar 11-13.

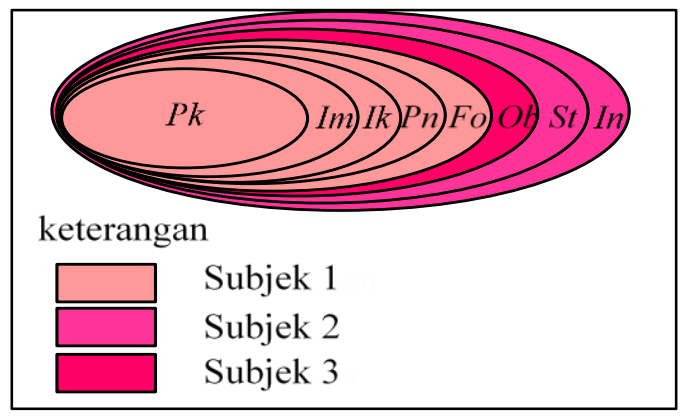

Gambar 11. Lapisan Pemahaman Konsep Soal Nomor 1

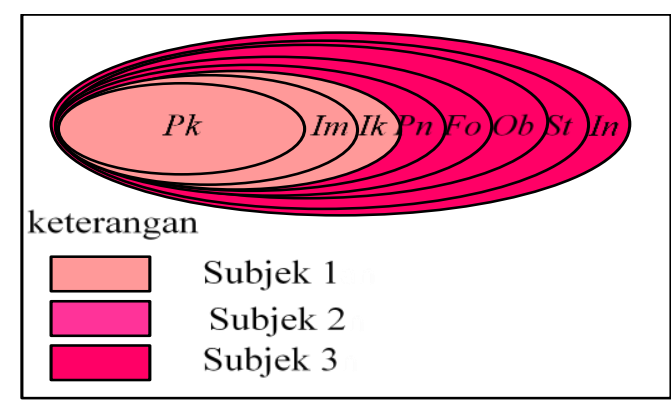

Gambar 12. Lapisan Pemahaman Konsep Soal Nomor 2 
DOI: https://doi.org/10.24127/ajpm.v8i1.1890

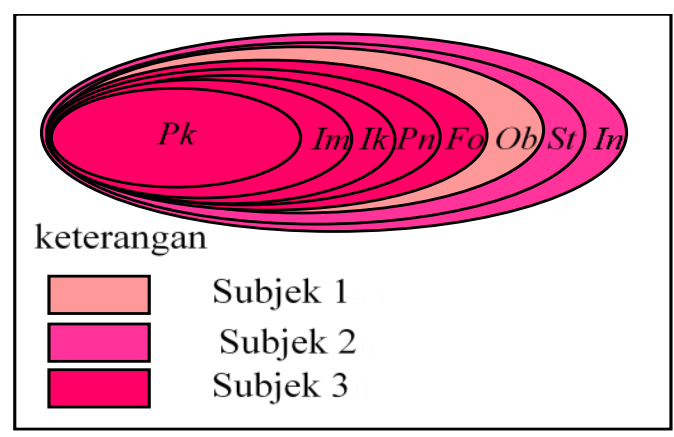

Gambar 13. Lapisan Pemahaman Konsep Soal Nomor 3

Berdasarkan hasil penelitian dapat dilihat bahwa setiap siswa memiliki kemampuan yang berberda dalam menyelesaikan permasalahan. Jika kemampuan siswa dalam memahami konsep juga berbeda-beda dan diukur, maka akan memberi implikasi yang cukup untuk mengetahui sejauh mana ukuran atau tingkatan pemahaman konsep di lapisan pemahamn konsep diatas.

Hal ini juga sejalan dengan penelitian Cahyati (2017), Sagala (2017) dimana setiap siswa memiliki pemahaman konsep tentang matematika yang berbeda-beda dan berpengaruh dalam lapisan pemahaman konsep. Utami (2016) juga siswa laki-laki dan siswa perempuan memiliki tingkat pemahaman konsep yang berbeda. Selain itu Safitri, Mulyani \& Ratu (2018) juga berpendapat bahwa lapisan pemahaman konsep siswa berbeda-beda sesuai dengan siswa yang berkemampuan tinggi, sedang, dan rendah.

\section{KESIMPULAN DAN SARAN}

Berdasarkan hasil penelitian yang telah dilakukan dapat disimpulkan bahwa lapisan pemahaman konsep terkait soal PISA konten quantity menunjukkan hasil yang berbeda-beda di setiap subjek serta soalnya. Pada soal nomor 1 mengenai banyaknya rata-rata pendaki Gunung Fuji setiap harinya menunjukkan bahwa Subjek 1 dapat mencapai pada lapisan pemahaman konsep yang kelima yaitu formalising, Subjek 2 dapat pada lapisan pemahaman konsep yang kedelapan yaitu inventising dan S3 dapat mencapai pada lapisan pemahaman observing. Kemudian pada soal nomor 2 mengenai rata-rata panjang langkah Putra saat berjalan disepanjang jalur Gotemba menunjukkan bahwa Subjek 1 dapat mencapai lapisan image making, Subjek 2 dan Subjek 3 dapat mencapai lapisan kedelapan yaitu inventising. Selanjutnya pada soal nomor 3 mengenai banyaknya penguin yang masih hidup di koloni pada akhir tahun pertama menunjukkan bahwa Subjek 1 dapat mencapai lapisan observing, Subjek 2 dapat mencapai lapisan pemahaman yang kedelapan yaitu inventising, dan S3 hanya mencapai pada lapisan formalising. Berdasarkan hasil penelitian juga menunjukkan terdapat subjek yang masih kurang menguasai konten quantity.

Adapun saran yang diberikan terkait penelitian ini yaitu diharapkan pada penelitian selanjutnya lebih mengembangkan instrumen, subjek agar dapat memperoleh perbedaan yang ada pada setiap subjek.

\section{DAFTAR PUSTAKA}

Cahyati, A. M., \& Kriswandani. (2017). Lapisan Pemahaman Konsep Matematika Dalam Menyelesaikan Soal TIMSS Bagi Siswa kelas X. Inspiramatika: Jurnal Inovasi Pendidikan dan Pembelajaran Matematika, 3(2). (Johar, 2012) 
Hawa, A. M., \& Putra, L. V. (2018). PISA untuk Siswa Indonesia. Jurnal Janacitta Universitas Ngudi Waluyo, 1(1).

Johar, R. (2012). Domain soal PISA untuk Literasi Matematika. Jurnal Peluang, 1(1).

OECD. (2012). Draft PISA 2012 Mathematics Framework. Retrieved March 12, 2018, from http://www.oecd.org/pisa/pisaprodu cts/46961598

Permendikbud. 2014. Peraturan Menteri Pendidikan dan Kebudayaan Republik Indonesia Nomor 59 Tahun 2014 Tentang Kurikulum 2013 Sekolah Menengah Atas / Madrasah Aliyah. Jakarta : Departemen Pendidikan dan Kebudayaan

Pirie, S., \& Kieren, T. (1994). Growth in Mathematical Understanding: How Can We characterise It and How Can We Represent it? Educational Studies in Mathematics, 26(2), 165-190.

Puspitasari \& Ratu, N. (2019). Deskripsi Pemahaman Konsep dalam Menyelesaikan Soal PISA pada Konten Space and Shape. Mosharafa : Jurnal Pendidikan Matematika, 8(1), 155-166.

Puspitasari, A. P., \& Prihatnani, E. (2018.) Deskripsi Pemahaman Konsep Kejadian Majemuk Siswa Kelas XI IPA SMA Negeri 3 Salatiga. e-Jurnal Mitra Pendidikan, 2(1), 117-133.

Rosnawati, R. (2012). Enam Tahapan Aktivitas dalam Pembelajaran Matematika untuk Mendayagunakan Berpikir Tingkat Tinggi Siswa (Makalah). Diambil tanggal 6 Maret 2018 dari http://staff.uny.ac.id

Safitri, R. I., Mulyani, S., \& Ratu, N. (2018). Profil Lapisan Pemahaman Konsep Siswa SMP Terkait Garis
Tinggi Segitiga. Soulmath, 6(2), 65-78.

Sagala, V. (2017). Profil Lapisan Pemahaman Konsep Turunan Fungsi dan Folding Back Mahasiswa Calon Guru Matematika Berdasarkan Gender. SoulMath, 4(5).

Utami, I. W., \& Rosyidi, A. H., (2016). Profil Lapisan Pemahaman Property Noticing Siswa Pada Materi Logaritma Ditinjau Dari Perbedaan Jenis Kelamin. Mathedunesa: Jurnal Ilmiah Pendidikan Matematika, 1(5). 